\title{
Removal of Iron using Isolated Bacteria (Vibrio alginolyticus) in seawater at Ship Dismantling Area
}

\author{
Harmin Sulistiyaning Titah ${ }^{1, *}$, Herman Pratikno ${ }^{2}$, and Atiek Moesriati ${ }^{1}$ \\ ${ }^{1}$ Department of Environmental Engineering, Faculty of Civil, Environmental and Geo Engineering, Sepuluh November Institute of \\ Technology, Keputih, Sukolilo, 60111 Surabaya, Indonesia \\ ${ }^{2}$ Department of Ocean Engineering, Faculty of Marine Technology, Sepuluh November Institute of Technology, Keputih, Sukolilo, \\ 60111 Surabaya, Indonesia
}

\begin{abstract}
The ship dismantling activity can cause heavy metal pollution in the environment. One of technology to remediate is bioremediation using bioaugmentation and/or biostimulation methods. The purpose of this research was to determine the removal of iron by Vibrio alginolyticus and nutrient addition. Vibrio alginolyticus was halophilic bacteria that isolated from seawater at this area. The laboratory test was conducted using size erlenmeyer of $250 \mathrm{~mL}$. The $5 \%(\mathrm{v} / \mathrm{v})$ of Vibrio alginolyticus suspension was added in each reactor. After that, the nutrient with ratio of $\mathrm{C}: \mathrm{N}: \mathrm{P}(100: 10: 1)$ also was added in each reactor. The removal test was carried out for 14 days. Concentration of iron was analyzed using Atomic Absorption Spectrophotometers (AAS). Based on the results, the percentage of iron removal at location 1 with treatment was $94.9 \pm 3.6 \%$. It showed a higher value than compared to iron removal at control 1 which was only $50.4 \pm 1.8 \%$. Whereas at location 2 , the percentage of iron removal with treatment reached $53.7 \pm 13.1 \%$ and it was only $16.7 \pm 13.1 \%$ at control 2 . This indicated that the treatment of the addition of Vibrio alginolyticus and nutrients can improve the iron remediation process.
\end{abstract}

Keywords: Bacteria; Remediation; Contamination; Heavy Metal; Nutrient; Ship Dismantling.

\section{Introduction}

Activity of shipbreaking or activity of ship demolition is an activity type of ship disposal that include the breaking up of ships become some parts [1]. The results of these activities can be sold or can be used depending on the requirement. These activities were also known as ship dismantling, ship cracking, or ship recycling. Countries such as China, India, Bangladesh, and Pakistan were countries that have many ship breaking activities [1]. The activities at ship breaking such as metal material recycle, engine reuse, winches reuse, power generators reuse, air conditioners reuse, refrigerators reuse, construction materials reuse have been conducted in the past. However, the ship recycling sector should be more focused on considering the impact on environment [2].

Economic benefits can be obtained from boat demolition activities. Besides that, the environment can be affected due to this activity. The process of cutting and scraping plates or scrapping the painted metal surface were some common operations during the ship breaking [3]. The pollutants released from those processes that have potential load into the intertidal area, sediments, sludge, and coast area. According to Deshpande et al. [3, 4], some of hazardous and toxic substance such as asbestos, glass wool, thermocol, oily rags, oily sludge, oily sand, polychlorinated biphenyl (PCB), polyaromatic hydrocarbons $(\mathrm{PAH})$, and organotins like tributyltin (TBT) can be released during the ship dismantling activities. Based on Barua (2017) [5], heavy metals that concern associated with shipbreaking activities were lead $(\mathrm{Pb})$, mercury $(\mathrm{Hg})$, cadmium $(\mathrm{Cd})$, iron $(\mathrm{Fe})$, aluminium $(\mathrm{Al})$, zinc $(\mathrm{Zn})$, copper $(\mathrm{Cu})$, chromium $(\mathrm{Cr})$ and manganese $(\mathrm{Mn})$.

Based on our earlier study, the iron pollution occurred at ship dismantling area in Madura Island both at seawater and sediment or coastal soil [6]. The concentration of $\mathrm{Fe}$ in seawater reached 1.03, 1.01 and $1.00 \mu \mathrm{g} / \mathrm{mL}$ at three sampling locations, respectively. Meanwhile, the concentration of extractable $\mathrm{Fe}$ in soil was $962.0,966.05,981.00 \mathrm{mg} / \mathrm{kg}$ at three sampling locations, respectively.

There are many technologies to remediate iron in water media. One of those technologies is bioremediation. Bioremediation is a biological technology to remediate heavy metals and organic pollutants that using naturally living organisms [7]. The principles of the bioremediation can be divided into several techniques. Those techniques are biofilters, bio-venting, bio-sorption, composting, bioaugmentation, bio-reactor, land farming and biostimulation [8]. Bioaugmentation is conducted using addition with suitable bacteria to enhance the bioremediation processes. The bacteria could be from

\footnotetext{
*Corresponding author: harminsulis@gmail.com , harmin st@its.ac.id
} 
contaminated areas or from other places Biostimulation is a method of bioremediation with nutrient addition to enhance the bioremediation processes. The nutrient that can be added is carbon, nitrogen, phosphate, potassium, and oxygen. The purpose of this research was to determine the removal of iron by bacteria of Vibrio alginolyticus and nutrient addition. Iron is an important element for Vibrio spp., but iron recovery is complicated by its tendency to form iron complexes that are insoluble in nature and their relationship with high-affinity iron-binding proteins in the host [9].

\section{Materials and Methods}

\subsection{Seawater Sampling}

Samples of seawater were taken at the ship dismantling activities in Tanjungjati, Madura, Indonesia. Seawater samples were taken below seawater surface at a depth of $20 \mathrm{~cm} \mathrm{[10].} \mathrm{Amount} 5 \mathrm{~L}$ of seawater was taken at two locations ship dismantling. Figure 1 showed the two locations of sampling. Table 1 showed the parameters at the two sampling locations.

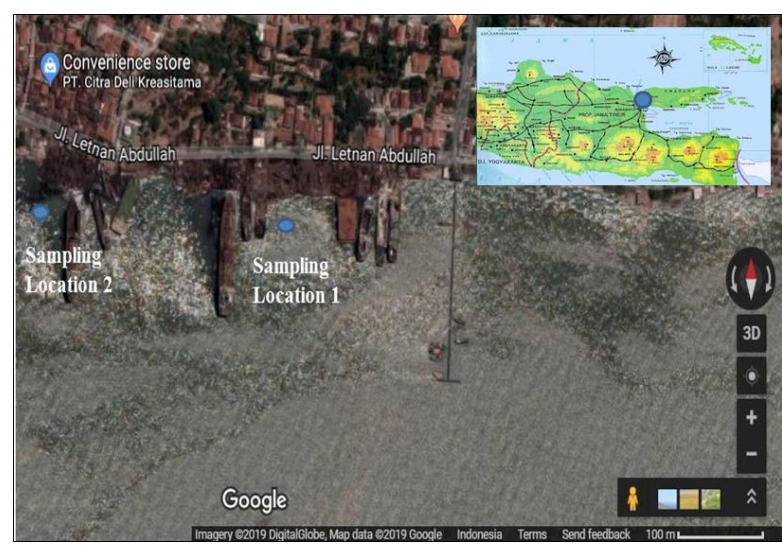

Fig. 1. Seawater sampling location.

Table 1. Font styles for a reference to a journal article.

\begin{tabular}{|c|c|c|}
\hline Parameter & Location 1 & Location 2 \\
\hline $\mathrm{pH}$ & 7.3 & 7.6 \\
\hline $\begin{array}{c}\text { Temperatu } \\
\text { re }\end{array}$ & $<32{ }^{\circ} \mathrm{C}$ & $<32^{\circ} \mathrm{C}$ \\
\hline Salinity & $28.4 \mathrm{ppt}$ & $28.2 \mathrm{ppt}$ \\
\hline $\begin{array}{c}\text { TOC }- \\
\text { Total } \\
\text { Organic } \\
\text { Carbon }\end{array}$ & $0.39 \%$ & $0.94 \%$ \\
\hline $\begin{array}{c}\text { Total N } \\
\text { Total P }\end{array}$ & $3.14 \mathrm{mg} / \mathrm{L} \mathrm{NH3-N}$ & $1.68 \mathrm{mg} / \mathrm{L} \mathrm{NH3-N}$ \\
\hline & $0.14 \mathrm{mg} / \mathrm{L} \mathrm{PO}-\mathrm{P}$ & $0.32 \mathrm{mg} / \mathrm{L} \mathrm{PO} 4-\mathrm{P}$ \\
\hline
\end{tabular}

\begin{tabular}{|c|c|c|}
\hline $\mathrm{Fe}$ & $3.93 \mathrm{mg} / \mathrm{L}$ & $0.54 \mathrm{mg} / \mathrm{L}$ \\
\hline $\mathrm{Mn}$ & $0.00 \mathrm{mg} / \mathrm{L}$ & $0.00 \mathrm{mg} / \mathrm{L}$ \\
\hline
\end{tabular}

\subsection{Bacteria Preparation}

Vibrio alginolyticus was halophilic bacteria that isolated from seawater in the same area based on our earlier research [11]. These bacteria have high resistance to iron. The stock of Vibrio alginolyticus was inoculated on a new selective media (ThiosulfateCitrate Bile Salts Sucrose - TCBS media, Merck, USA). The TCBS agar is a media for the selective isolation of Vibrio spp.

\subsection{Iron Removal Test}

The iron removal laboratory test was conducted using size erlenmeyer flasks of $250 \mathrm{~mL}$ as a reactor. The code of reactors was $\mathrm{R} 1$ for treatment sample location 1, R2 for treatment sample location 2, K1 for control of R1, K2 for control of R2. All tests were carried out a duplicate. The $5 \%(\mathrm{v} / \mathrm{v})$ of Vibrio alginolyticus suspension was added in each reactor. After that, the nutrient with a ratio of $\mathrm{C}: \mathrm{N}: \mathrm{P}(100: 10: 1)$ also was added in each reactor. The calculation of nutrient addition was conducted based on data of TOC, Total $\mathrm{N}$ and Total $\mathrm{P}$. The addition nutrient was $\mathrm{NH}_{4} \cdot 2 \mathrm{H}_{2} \mathrm{O}$ pro analysis (Merck, USA) and $\mathrm{KH}_{2} \mathrm{PO}_{4}$ and $\mathrm{K}_{2} \mathrm{HPO}_{4}$ pro analysis (Merck, USA). The removal test was carried out for 14 days.

\subsection{Parameter Analysis}

Analysis of iron concentration from seawater samples was carried using methods based on SNI 06-6989.4 (2004) [12]. The concentration of iron was analyzed using an Atomic Absorption Spectrophotometer (AAS) instrument, Hitachi model Z-2000 Series (Japan) at Laboratory of Energy, ITS. The monitoring parameters such as $\mathrm{pH}$, temperature, salinity, dissolved oxygen (DO) and Colony Form Unit (CFU) were also measured. Analysis of CFU was conducted based on Harley and Prescot Method [13].

\subsection{Statistical Analysis}

The experimental data of iron removal percentages were subjected to an analysis of variance (ANOVA) using SPSS Statistics for Windows version 21.0 (SPSS, Inc., Chicago, IL). Statistical significance was defined as $\mathrm{p}<0.05$.

\section{Results and Discussions}

Figure 2 until Figure 5 showed the monitoring parameters during the iron removal test. The $\mathrm{pH}$ value during the iron removal test showed that $\mathrm{pH}$ was in the normal $\mathrm{pH}$ range of $5.80-6.87$ (Fig. 2). $\mathrm{The}^{\mathrm{pH}}$ of 
Vibrio alginolyticus was regulated at around 7.6-7.4 and the $\mathrm{pH}_{\text {out }}$ ranged around 6.4-9.0 [14,15]. Vibrio alginolyticus showed acceptable growth at $\mathrm{pH}$ values ranging from $4.5-5$ to $10.5-11$ under suitable temperature and salinity concentration [16].

Temperature during the test was $28.5-30.6{ }^{\circ} \mathrm{C}$ (Figure 3). According to Farid and Larsen [16], Vibrio alginolyticus can grow at temperature of 10 $42^{\circ} \mathrm{C}$. The value of DO during the test was $3.46-3.73$ $\mathrm{mg} / \mathrm{L}$ (Figure 4), this showed the process was under aerobic conditions. According to Sihag et al. [17], in stoichiometric aerobic bacteria, it needed $3.1 \mathrm{mg} \mathrm{mL}$ of oxygen to degrade $1 \mathrm{mg} / \mathrm{mL}$ of hydrocarbons without considering the total bacterial mass.

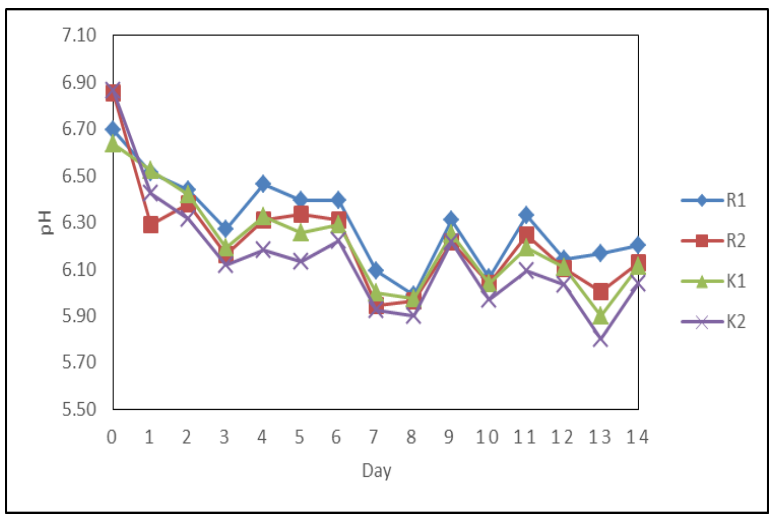

Fig. 2. pH during iron removal test

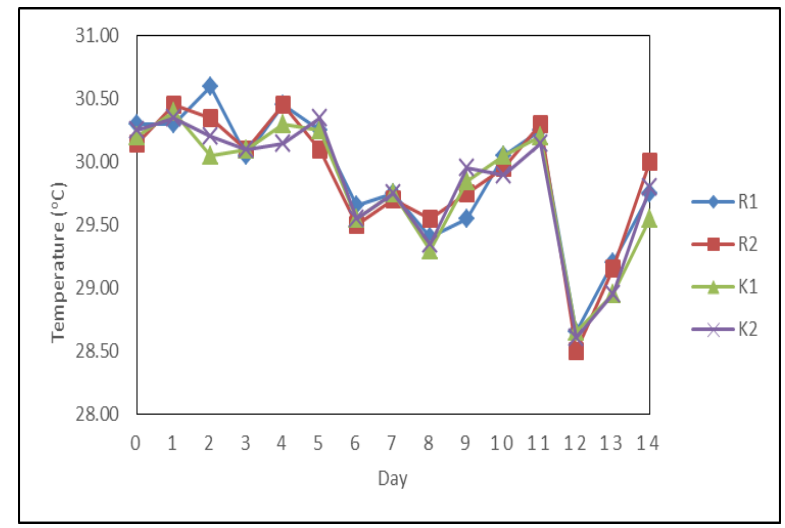

Fig. 3. Temperature during iron removal test

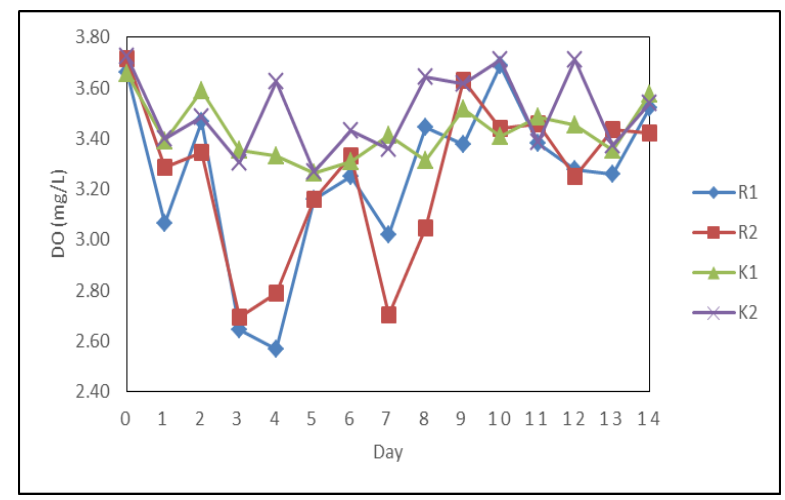

Fig. 4. DO during iron removal test

The range of salinity was $26-31.85$ ppt or $26-$ $31.85 \%$ during test (Fig. 5). According to Farid and
Larsen [16], Vibrio alginolyticus showed the most suitable growth rate in a $30 \%$ of salinity solution (seawater salinity). Meanwhile, the growth of those bacteria decreased in a $60 \%$ of salinity solution (higher than seawater salinity) and it showed the lowest growth occurred in the $5 \%$ of salinity solution (freshwater).

Figure 6 showed the population of Vibrio alginolyticus during iron removal test. The CFU in R1 and R2 showed the higher than in control 1 and control 2. It indicated that the population of Vibrio alginolyticus increased after Vibrio alginolyticus addition on treatment reactor. However, Vibrio alginolyticus presence in reactor without addition of this bacteria. It estimated that Vibrio alginolyticus had been presence at the location due to Vibrio alginolyticus was as a indigeneous bacteria. Based on our previous study, Vibrio alginolyticus were isolated at ship dismantling area that has high resistance on iron [6].

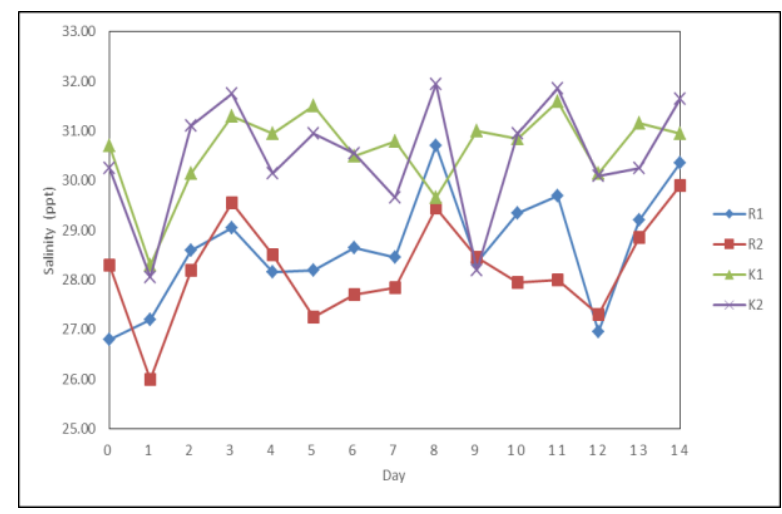

Fig. 5. Salinity during iron removal test

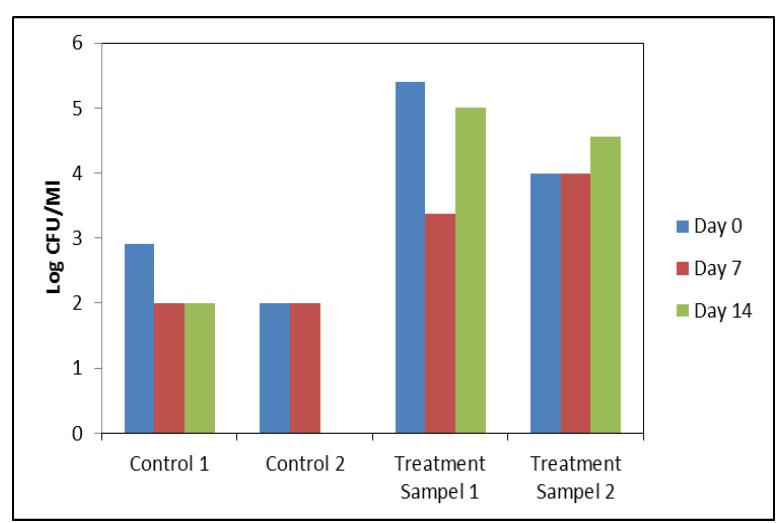

Fig. 6. CFU during iron removal test

Based on Figure 7, the percentage of iron removal at location 1 with treatment was $94.9 \pm 3.6 \%$. It showed a higher value than compared to iron removal at control 1 which was only $50.4 \pm 1.8 \%$. Whereas at location 2, the percentage of iron removal with treatment reached $53.7 \pm 13.1 \%$ and it was only $16.7 \pm$ $13.1 \%$ at control 2 . This indicated that the treatment of the addition of Vibrio alginolyticus and addition of nutrients can improve the iron bioremediation process. 
According to El-Hendawy et al. [18], Vibrio alginolyticus isolated from a metal industrial area has a maximum tolerance concentration of heavy metals. That maximum tolerance reached $2.5 \mathrm{mM}$ of $\mathrm{Cd}, 4$ $\mathrm{mM}$ of $\mathrm{Cu}, 2.5 \mathrm{mM}$ of $\mathrm{Pb}$ and $3.5 \mathrm{mM}$ of $\mathrm{Zn}$. The ability of those bacteria to remove heavy metal from the solutions that were polluted with heavy metals were $20 \%$ for $\mathrm{Cd}, 31 \%$ for $\mathrm{Cu}, 40 \%$ for $\mathrm{Pb}$ and $45 \%$ for Zn. Based on our previous research, Vibrio alginolyticus can survive on $2.000 \mu \mathrm{g} / \mathrm{mL}$ of iron.

The are many processes of bioremediations that are involved in microbe-heavy metals interaction. Those processes are adsorption process, complexation process, precipitation process, oxidation process and reductions process [7]. The heavy metals bioremediation potential occurred through microbeheavy metals interactions [7]. According to Davies and Bennett (1983) [19], Ford and Mitchell (1992) [20], the chemical reactions between microbe and metal ions are divided into six types of processes. The first process is intracellular accumulation, second process is reaction of cell wall-associated with metals. Third process is extracellular mobilization or it also known as immobilization of metals. Fourth process is metal siderophore interactions process. Fifth process is extracellular polymer metals interaction with transformation. And the last process is volatilization of metals to air environment.

Species of Vibrio have developed a variety of iron transportation systems that allow bacteria to compete for this important element in each of their habitats [9]. The mechanism of iron reduction by Vibrio alginolyticus was predicted through using the system including the secretion system and absorption system of high-affinity iron-binding agents (siderophores) and transportation systems for iron bound to the host complex. System transporters for iron ferric and ferrous iron not complexed to siderophores were also common to Vibrio species for iron removal [9].

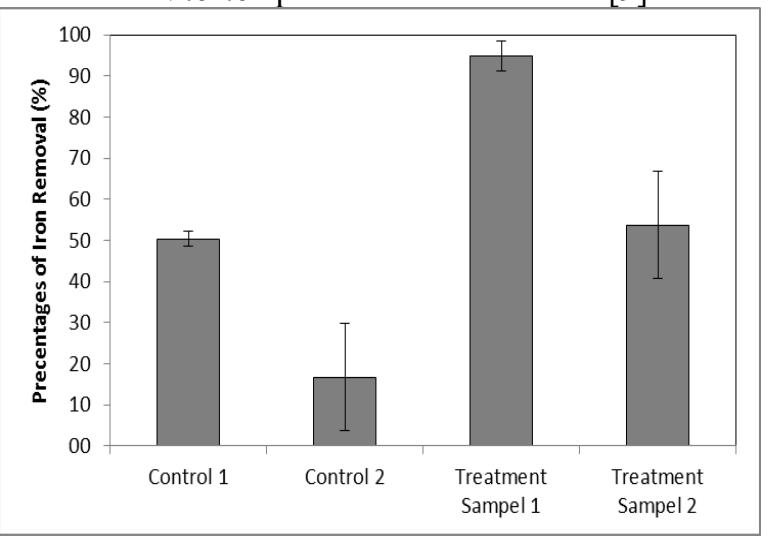

Fig. 7. Removal percentages of iron

Based on oneway ANOVA analysis, the removal of iron at treatment reactors and control reactors showed a significant difference with $\mathrm{p}<0.05$. It indicated that Vibrio alginolyticus and the nutrient addition can improve the removal of iron in seawater. Based on Ulitzur [21], nutrient concentration affected the Vibrio alginolyticus growth, so that the ratio of nutrient should be suitable for reaching the optimum growth.

\section{Conclusion}

The percentage of iron removal at location 1 with treatment was $94.9 \pm 3.6 \%$. It showed a higher value than compared to iron removal at control 1 which was only $50.4 \pm 1.8 \%$. Whereas at location 2 , the percentage of iron removal with treatment reached $53.7 \pm 13.1 \%$ and it was only $16.7 \pm 13.1 \%$ at control 2. In conclusion, Vibrio alginolyticus was potential to be used for removal of iron in contaminated seawater.

The author would like to thank KemenristekDIKTI (Ministry of Research, Technology and Higher Education, Republic of Indonesia) through scheme of Penelitian Terapan Unggulan Perguruan Tinggi - third year research, PTUPT 2019 for funding this research No of contract, 5/E1/KP.PTNBH/2019 and No. 998/PKS/ITS/2019.

\section{References}

1. T. Karlis, D. Polemis, Sci. J. of Maritime Res. 30, 128132 (2016)

2. D.M. Hiremath. Proceedings of the International Conference on Advances in Civil and Environmental Engineering (2017)

3. P.C. Deshpande, A.K.Tilwankar, P.P. Kalbar, S.R. Asolekar. Sci. of The Total Environ. 438, 304-311 (2012)

4. P.C. Deshpande, P.P. Kalbar, A.K.Tilwankar, S.R. Asolekar. J. of Clean. Produc. 59, 251-259 (2013)

5. P. Barua. Asian profile 45, 2 (2017)

6. H.S. Titah, H. Pratikno, A. Moesriati, R.P. Islami, M.F. Imron. AASEC MATEC Web of Conferences 197, 13020 (2018)

7. S. Siddiquee, K. Rovina, S. Al Azad, L. Naher, S. Suryani, P. Chaikaew. J Microb. Biochem. Technol. 7:6 (2015)

8. J.P. Huang, C.P. Huang, A.L. In: J.P. Vernet, Heavy Metals in the Environment, Elsevier London (1991)

9. S.M. Payne, A. R. Mey, E. E. Wyckoff. Microbiol. and Molecul. Biol. Rev. 80(1), 69-90 (2016)

10. S.K. Bhasheer, S. Umavathi, D. Banupriya, M. Thangavel, Y. Thangam, Y. Int. J. Curr. Microbiol. App. Sci. 3(11), 363-369 (2014)

11. H.S. Titah, H. Pratikno, A. Moesriati, Research Report on Biroremediation (2017)

12. SNI 06-6989.4. Method for Fe analysis using AAS (2004)

13. J.P. Harley, L.M. Prescott, Laboratory exercises in microbiology 5th Edition, McGraw-Hill Companies Texas (2002)

14. T. Nakamura, H. Tokuda, T. Unemoto. Biochimica Et Biophysica Acta 776, 330-336 (1984)

15. T. Nakamura, S. Kawasaki, T. Unemoto. J. of Gen. Microbiol. 138, 1271-1276 (1992)

16. A.F. Farid, J.L. Larsen. Systematic and Applied Microbiology 68-75 (1981)

17. S. Sihag, H. Pathak, D.P. Jaroli. Int. J. of Pure Appl. Biosci. 2(3), 185-202 (2014)

18. H.H. El-Hendawy, D.A. Ali, E.H. El-Shatoury, S.M. Ghanem. Egypt. Acad. J. biolog. Sci. 1(1), 23-28 (2009) 
19. D.J.A. Davies, B.G. Bennett, Exposure Commitment Assessment of Environment pollutants Vol. 3 MARC (Monitoring and Assessment Research Centre) Report Number 30 (MARC Publication, London,1983)

20. T. Ford, M. Mitchell, Microbial Transport of Toxic Metals: Environmental Microbiology, John Wiley and Sons New York (1992)

21. S. Uliizur, Microbial Ecolog. 1(3), 127-135 (1974) 